\title{
Review
}

\section{Interleukin-31 and Pruritic Skin}

\author{
Masutaka Furue $^{1, *,+}$ i and Mihoko Furue ${ }^{2}$
}

check for updates

Citation: Furue, M.; Furue, M. Interleukin-31 and Pruritic Skin. J. Clin. Med. 2021, 10, 1906. https:// doi.org/10.3390/jcm10091906

Academic Editor: Shawn G. Kwatra

Received: 12 March 2021

Accepted: 23 April 2021

Published: 28 April 2021

Publisher's Note: MDPI stays neutral with regard to jurisdictional claims in published maps and institutional affiliations.

Copyright: (c) 2021 by the authors. Licensee MDPI, Basel, Switzerland. This article is an open access article distributed under the terms and conditions of the Creative Commons Attribution (CC BY) license (https:/ / creativecommons.org/licenses/by/ $4.0 /)$.

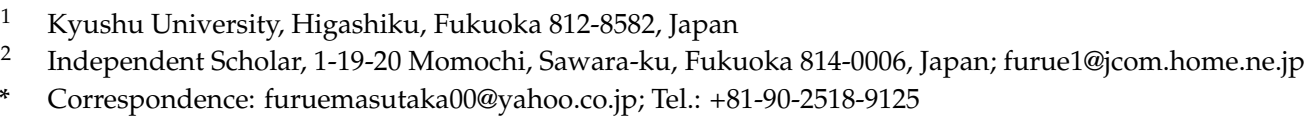

\begin{abstract}
Skin inflammation often evokes pruritus, which is the major subjective symptom in many inflammatory skin diseases such as atopic dermatitis and prurigo nodularis. Pruritus or itch is a specific sensation found only in the skin. Recent studies have stressed the pivotal role played by interleukin-31 (IL-31) in the sensation of pruritus. IL-31 is produced by various cells including T helper 2 cells, macrophages, dendritic cells and eosinophils. IL-31 signals via a heterodimeric receptor composed of IL-31 receptor A (IL-31RA) and oncostatin M receptor $\beta$. Recent clinical trials have shown that the anti-IL-31RA antibody nemolizumab can successfully decrease pruritus in patients with atopic dermatitis and prurigo nodularis. The IL-31 pathway and pruritic skin are highlighted in this review article.
\end{abstract}

Keywords: IL-31; pruritus; itch; atopic dermatitis; prurigo nodularis; nemolizumab; Th2 cell; macrophage; dendritic cell

\section{Introduction}

Pruritus or itch is a specific sensation of the skin leading to a scratching behavior mostly recognized in terrestrial mammals [1,2]. Acute pruritus is typically not a major problem. However, chronic pruritus that lasts more than 6 weeks is highly problematic because it markedly deteriorates quality of life, mental health and sleep quality in the afflicted individuals [1-5]. Chronic pruritus is the major symptom in many inflammatory skin diseases such as atopic dermatitis, prurigo nodularis, eczema, chronic urticaria and psoriasis [1-4]. Scratching clearly exacerbates the predisposing dermatitis, which may further enhance pruritus and result in an itch/scratch vicious cycle [6].

Recent studies have revealed numerous itch-inducing factors or pruritogens $[1-4,7,8]$. Specific receptors for these pruritogens are expressed on cutaneous sensory nerve fibers, which are mostly small C-fibers innervating the epidermis and dermis [9]. Representative pruritogens and their receptors are listed in Table 1.

Table 1. Representative pruritogens and their receptors.

\begin{tabular}{cc}
\hline Pruritogens & Receptors \\
\hline Histamine & Histamine H1 receptor (H1R), \\
\hline $\begin{array}{c}\text { BAM8-22, SLIGRL, } \\
\text { Cathepsin S }\end{array}$ & Mas-related \\
\hline Chloroquine & Mrgprotein-coupled receptor C11 (MrgprC11) \\
\hline 5-Hydroxytriptamine (5-HT), \\
LY344864 \\
\hline Substance P & 5-Hydroxytriptamine receptor 1F \\
\hline Opioid & Neurokinin 1R (NK1R) \\
\hline
\end{tabular}


Table 1. Cont.

\begin{tabular}{cc}
\hline Pruritogens & Receptors \\
\hline Leukotriene B4 & Leukotriene B4 receptor 1 (BLT1R) \\
\hline Endothelin-1 & Endothelin receptor type A (ETAR) \\
\hline $\begin{array}{c}\text { SLIGRL, Tryptase, } \\
\text { Mucunain, Cathepsin S }\end{array}$ & $\begin{array}{c}\text { Proteinase-activated receptor-2 } \\
\text { (PR-2) }\end{array}$ \\
\hline $\begin{array}{c}\text { AYPGKF, Mucunain, } \\
\text { Cathepsin S }\end{array}$ & PAR-4 \\
\hline IL-31 & IL-31 receptor A (IL-31RA)/ \\
\hline Oncostatin M receptor (OSMR) \\
\hline IL-4/IL-13 & IL-4 receptor $\alpha$ (IL-4R $\alpha) /$ \\
IL-13 receptor $\alpha 1$ (IL-13R $\alpha 1)$ \\
\hline Thymic stromal lymphopoietin \\
(TSLP) & TSLP receptor (TSLPR)/ \\
IL-33 & IL-7 receptor $\alpha($ IL-7R $\alpha)$ \\
\hline
\end{tabular}

* $\mathrm{k}$-Opioid receptor agonists nalfurafine and difelikefalin inhibit $\mu$-opioid receptor.

Among these pruritogens, particular attention has been paid to interleukin-31 (IL-31), since systemic administration of the anti-IL-31 receptor A (IL-31RA) antibody nemolizumab successfully ameliorates chronic itch in patients with atopic dermatitis and prurigo nodularis $[10,11]$.

\section{IL-31 and Its Signaling}

IL-31 belongs to the gp130/IL-6 cytokine family [12]. It was originally reported to be preferentially produced by T helper type 2 (Th2) cells [12]. IL-31 is expressed in Th2, but not in Th1, Th17 and Th22, clones [13]. The production of IL-31 in Th2 clones is dependent on their autocrine IL-4 production [13]. IL-33 strongly potentiates the IL-4-induced IL-31 production in Th2 clones [13]. Th1 clones can produce IL-31 in the presence of IL-4, but only transiently [13].

In addition, IL-31 is expressed by other hematopoietic cells including macrophages (especially M2 macrophages), dendritic cells, mast cells, basophils and eosinophils [12,14-18]. Even epidermal and sweat gland keratinocytes may possibly produce it [19-21]. Ultraviolet (UV)B irradiation or oxidative stress upregulates the IL-31 expression in T cells, monocytes, macrophages, and immature and especially mature dendritic cells [21]. Oxidative stress, but not UVB irradiation, also induces IL-31 expression in keratinocytes [21].

The production of IL-31 is upregulated by IL-4-mediated activation of signal transducer and activator of transcription 6 (STAT6) or by IL-33-mediated NF-KB activation [22], while it is downregulated by the activation of suppressor of cytokine signaling 3 (SOCS3) [23]. Staphylococcal enterotoxin B and staphylococcal $\alpha$-toxin are potent inducers of IL-31 from peripheral blood mononuclear cells, probably via toll-like receptor (TLR)-4 activation [24-26]. Interestingly, transforming growth factor- $\beta 1$ (TGF- $\beta 1$ ) decreases IL-31 production in Th2 cells [22], but it enhances that in dendritic cells [18]. Endothelial PAS domain protein 1 (EPAS1), also called hypoxia-inducible factor- $2 \alpha$, is one of the direct targets of STAT6 and acts as a hub protein in IL-4-mediated transcription networks in human T cells [27]. The binding of Epas1 and another transcription factor, Sp1, to the promoter region of the Il31 gene is indispensable for IL-31 production by IL-4 [28].

The interaction of Epas1 and Sp1 has been reported in hypoxic conditions [29,30]. As the expression of EPAS1 is also upregulated by TGF- $\beta 1$ [31] and TLR-4 ligation [32], EPAS1 may also potentially be involved in TGF- $\beta 1$-induced or TLR-4-induced IL-31 upregulation. On the other hand, macrophages express neurokinin 1 receptor (NK1R) (receptor for substance P), CD163 (receptor for hemosiderin) and $\alpha \mathrm{V}$ integrin (receptor for periostin) [16]. In macrophages, periostin upregulates IL-31 expression, which is further enhanced by 
substance $P$ and hemosiderin [16]. This recent evidence suggests that IL-31 expression may be regulated promiscuously by diverse signaling pathways.

IL-31 binds and activates a heterodimeric receptor composed of IL-31 receptor A (IL-31RA) and oncostatin M receptor $\beta$ (OSMR $\beta$ ) [12]. The heterodimeric IL-31R is known to be expressed on sensory neurons, macrophages, dendritic cells, basophils and epithelial cells including keratinocytes [12]. Intriguingly, $\mathrm{CD}^{+} \mathrm{T}$ cells do not express IL-31RA [33]. IL-4 enhances the expression of IL-31RA in macrophages and dendritic cells [34,35], but not in keratinocytes [36]. Its expression is augmented by interferon- $\gamma$ or TLR2 ligands in keratinocytes [36-38]. IL-31 itself does not affect IL-31RA expression [38]. Stimulation of IL-31RA/OSMR $\beta$ by IL-31 activates the downstream Janus kinase 1 (JAK1)/JAK2 and STAT3 (and also to a lesser extent STAT1 and STAT5) signaling pathway [39] (Figure 1).

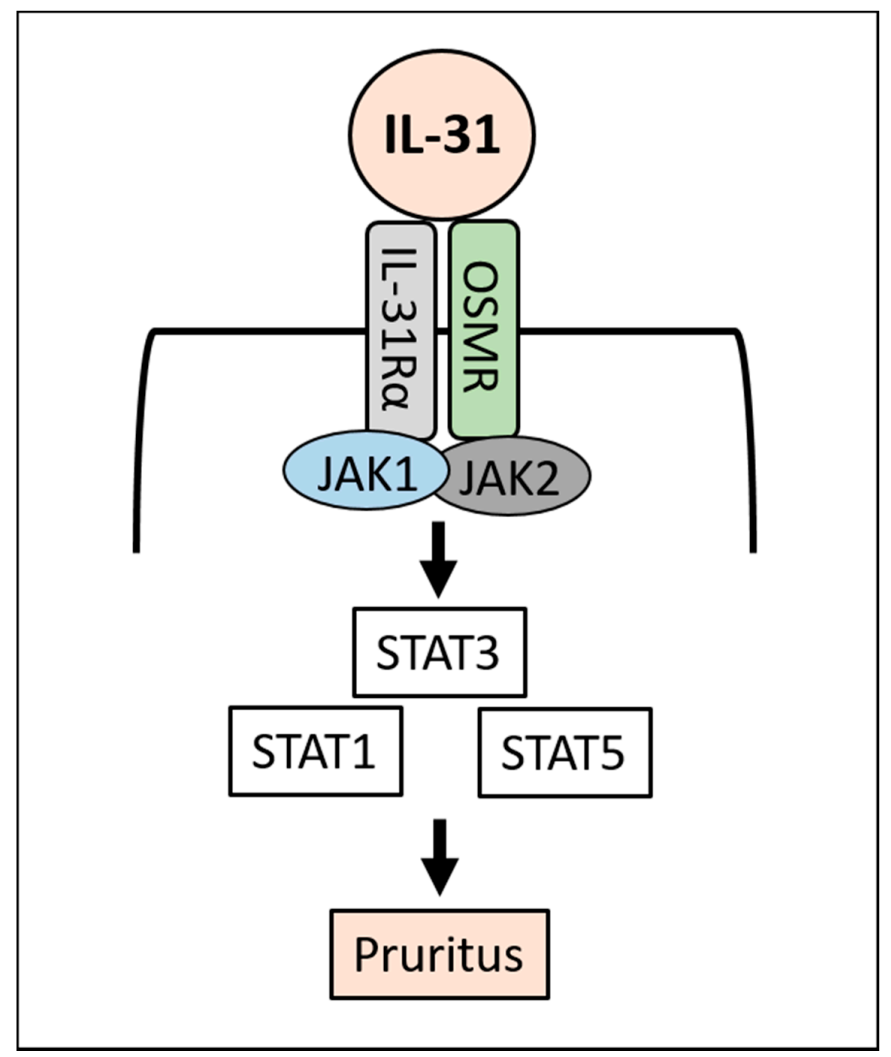

Figure 1. IL-31 signaling.

IL-31 binds to IL-31 receptor (IL-31RA/OSMR $\beta$ ) and activates JAK1/JAK2 and downstream STAT3 (to a lesser extent STAT1 and STAT5), then induces pruritus.

\section{IL-31 and Pruritus}

The most prominent pathophysiological function of IL-31 is that it is a pruritogenic cytokine in mammals [12]. Despite the low interspecies homology of the IL31 gene, it induces pruritus and scratch response in rodents, dogs, cynomolgus monkeys and humans [39-46]. Continuous scratching behaviors are observed in IL-31 transgenic mice, which results in the development of atopic dermatitis-like skin lesions [39]. In addition, the administration of IL-31 intravenously, intradermally, subcutaneously or intrathecally induces severe pruritus in normal mice [39-41,47,48]. Continuous or repeated injection of IL-31 also evokes sustained scratching and the development of dermatitis [47,48]. Moreover, Il31 ra-deficient mice do not develop pruritus and dermatitis in response to mouse IL-31 [39], and the administration of an anti-mouse IL-31 antibody ameliorates the scratching behavior in NC/Nga mice with atopic dermatitis-like skin lesions [49]. However, the IL-31-induced 
pruritus is not significantly attenuated by H1-antihistamine, dexamethasone, tacrolimus or $\mu$-opioid receptor antagonist in mice [41].

As described in previous review articles [7,50,51], the sensation of pruritus in the skin is mediated by cutaneous sensory nerves of small diameter (C-fibers or thinly myelinated A $\delta$-fibers) originating from dorsal root ganglion (DRG) neuronal cells, and is transmitted to the spinal cord and hypothalamic tract, and ultimately to the brain. Recent studies have demonstrated various pruritogens, pruritogen-specific neurotransmitters and their receptors $[7,50,51]$ (Table 1). BAM8-22, SLIGR and cathepsin S induce pruritus via Mas-related G-protein-coupled receptor C11 (MrgprC11) [9]. Most MrgprC11 ${ }^{+}$cutaneous sensory neurons are positive for substance $\mathrm{P}$ and calcitonin gene-related peptide (CGRP) in mice [9] (Figure 2).

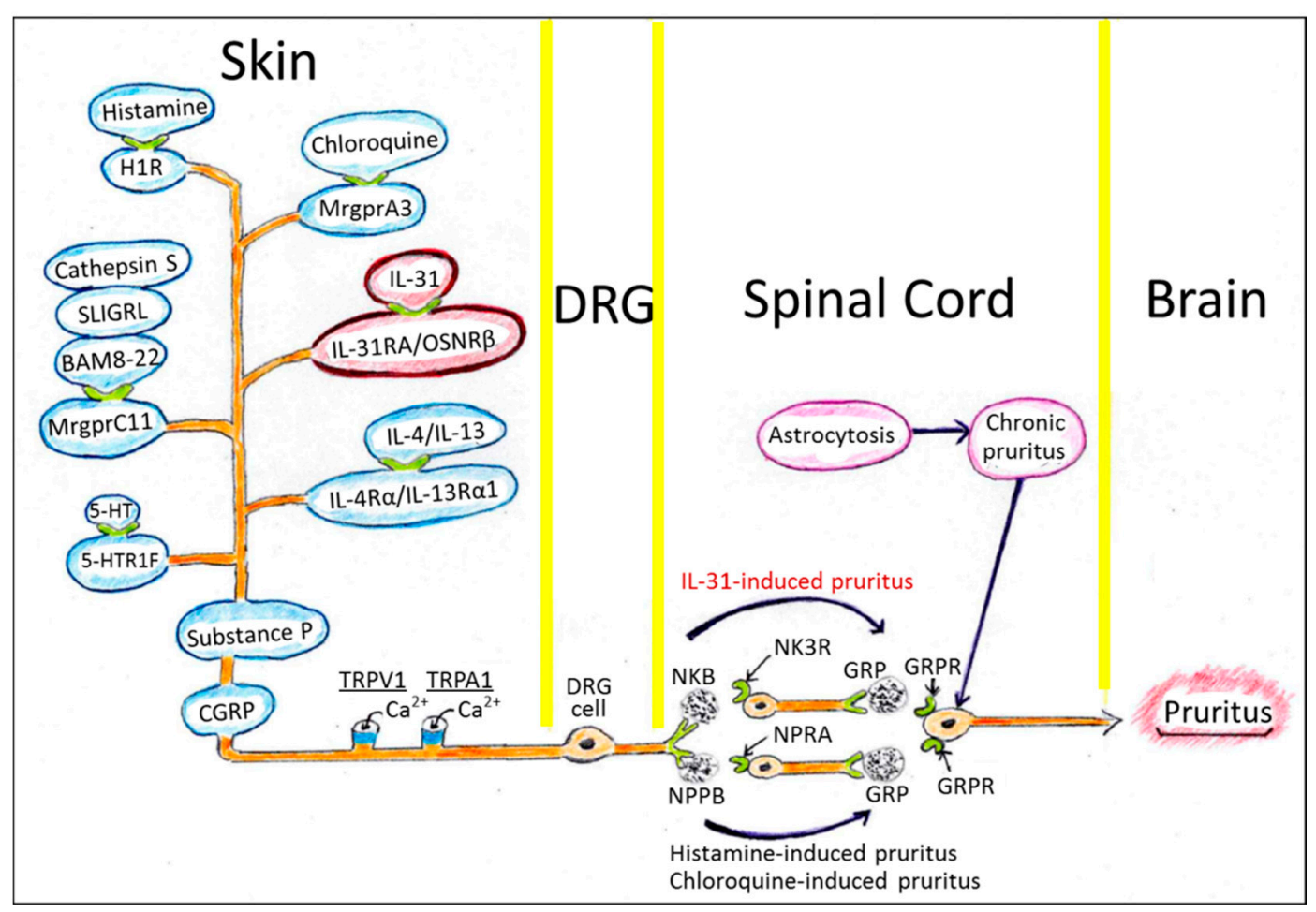

Figure 2. Murine sensory nervous system transmitting the sensation of pruritus.

The murine MrgprC11 ${ }^{+}$cutaneous sensory neurons also coexpress IL-31RA/OSMR $\beta$, histamine H1 receptor (H1R), MrgprA3 and 5-hydroxytryptamine receptor 1F (5-HTR1F) [9]. The expression of IL-31RA has also been confirmed in cutaneous neurons and DRG in cynomolgus monkeys and humans $[45,52]$. These human and mouse IL-31RA ${ }^{+}$neurons express transient receptor potential vanilloid 1 (TRPV1), which is an ion channel for $\mathrm{Ca}^{2+}$ and to a lesser extent $\mathrm{Na}^{+}$[9,40]. IL-31-induced itch is significantly reduced in Trpo1deficient mice [40]. IL-31-induced itch is also significantly reduced in mice deficient in Trpa1, which is required for itch sensation mediated by MargprA3 [40]. IL-31RA ${ }^{+}$DRG cells also coexpress IL-4R $\alpha /$ IL-13R $\alpha 1$, which is a heterodimeric receptor for IL-4 and IL-13 [53]. IL-4 and IL-13 themselves are pruritogenic cytokines [54]. More importantly, IL-4 and IL-13 further enhance the IL-31-evoked or histamine-evoked action potential in DRG cells, suggesting their participation in chronic itch formation [53].

Many pruritogenic axes such as chloroquine/MrgprA3- or histamine/H1R-induced pruritus require natriuretic polypeptide $\mathrm{b}(\mathrm{Nppb})$ and gastrin-releasing peptide (GRP) and their respective receptors, natriuretic peptide receptor A (NPRA) and GRP receptor (GRPR), to transmit the sensation of itch in the spinal cord $[55,56]$ (Figure 2). However, IL-31-induced pruritus requires neurokinin B (NKB) instead of Nppb [56]. NKB binds 
neurokinin receptor 3 (NK3R) and induces the release of GRP, which mediates the sensation of pruritus [56] (Figure 2).

The majority of Mas-related G-protein-coupled receptor C11 (MrgprC11)-positive murine sensory nerve fibers possess substance P and CGRP. MrgprC11 ${ }^{+}$sensory nerve fibers are positive for TRPV1 and TRPA1 which evokes action potential mainly via $\mathrm{Ca}^{2+}$. These MrgprC11 ${ }^{+}$sensory nerve fibers mostly coexpress IL-31 receptor (IL-31RA/OSMR $\beta$ ), which signals IL-31-induced pruritus to DRG neurons, the spinal cord, the hypothalamic tract and finally to the brain. The IL-31-induced pruritus is mediated by NKB and its receptor NK3R, and then by GRP and its receptor GRPR. Most MrgprC11 ${ }^{+}$nerve fibers also coexpress other pruritogenic receptors such as H1R for histamine, MrgprA3 for chloroquine, 5-HTR1F for serotonin and IL-4R $\alpha /$ IL-13R $\alpha 1$ for IL-4/IL-13. Pruritus by histamine and chloroquine is mediated by NPPB and its receptor NPRA, and then by GRP-GRPR signaling. Chronic pruritus is known to be associated with astrocytosis of the spinal cord. Many abbreviated molecules are listed in Table 1.

In addition to mediating the sensation of pruritus, IL-31 promotes nerve fiber elongation and the branching of murine small-diameter DRG neurons [48,57], which is abrogated in DRG neurons from Il31ra-deficient mice [48]. Moreover, the IL-31-induced nerve fiber elongation is independent of TRPV1 but dependent on STAT3 activation [48]. Interestingly, STAT3 also plays a pivotal role in the formation of reactive astrogliosis in the spinal cord, which causes chronic itch [58]. Targeting the STAT3 axis is thus a potential strategy for treating chronic pruritus (Figure 2).

\section{IL-31 and Keratinocytes}

In addition to its pruritogenic function, IL-31 is known to directly inhibit the differentiation of keratinocytes by downregulating the expression of barrier/differentiation-related proteins such as filaggrin, involucrin and cytokeratin 10, which results in the disruption of epidermal barrier function $[38,59,60]$. IL-31 also increases the expression of IL-1 $\alpha$, IL-20 and IL-24 in keratinocytes and these cytokines are partly responsible for IL-31-mediated downregulation of skin barrier formation $[38,60]$. In contrast, IL-31 increases the production of antimicrobial peptides such as S100A7 and defensin $\beta 4$ [60]. Significant amounts of IL-31 are detected in human sweat [20]. Upon stimulation with IL-31, keratinocytes can produce CCL2 [20]. However, the pathophysiological role of IL-31 in keratinocyte biology is not fully understood.

\section{IL-31 in Skin Diseases with Pruritus}

As IL-31 is a potent pruritogenic cytokine, its levels in skin and serum have been examined in various pruritic skin diseases. Increased IL-31 expression was found in lesional and nonlesional skin of patients with atopic dermatitis [24,61,62]. In addition, IL-31-expressing T cells are increased in the lesional skin of atopic dermatitis [62]. Serum levels of IL-31 are well correlated with disease severity in atopic patients $[63,64]$. Serum levels of IL-31 are elevated in canine atopic dermatitis and are significantly correlated with the pruritus score of afflicted dogs [65].

Prurigo nodularis is associated with severe pruritus. In this condition, the intensity of pruritus is correlated with the numbers of dermal IL- $31^{+}$cells and dermal IL-31RA ${ }^{+}$ cells [17]. Major cellular sources of dermal IL-31 are T cells and macrophages, while IL-31RA-expressing cells are mostly mast cells and macrophages [17].

The number of IL-31RA ${ }^{+}$or OSMR $\beta^{+}$cells is also correlated with pruritus intensity in patients with bullous pemphigoid [15]. Most of the dermal cells expressing IL-31 are eosinophils in bullous pemphigoid [15].

The majority of IL-31-expressing cells are $\mathrm{CD}^{+} 8^{+}$macrophages in stasis dermatitis [16]. The number of IL- $31^{+} \mathrm{CD} 68^{+}$cells was shown to be significantly increased in stasis dermatitis with severe pruritus compared with that without severe pruritus [16]. These $\mathrm{CD}^{+} 8^{+}$macrophages also coexpress CD163 and are classified as M2 macrophages [16]. 
The preferential expression of IL-31 in $\mathrm{CD}_{163^{+}} \mathrm{M} 2$ macrophages also occurs in scabies infection [14].

Serum levels of IL-31 are significantly elevated in patients with chronic pruritus of unknown origin compared with those in healthy controls [66]. In addition, serum IL-31 levels are significantly increased in patients with chronic urticaria or psoriasis; however, no significant correlation was found between pruritus intensity and IL-31 levels in these diseases [67].

In patients receiving hemodialysis, individuals with uremic pruritus have significantly increased serum levels of IL-31 compared with the levels in those without pruritus [68]. Oweis et al. measured serum levels of IL-31, IL-13 and IL-33 in hemodialysis patients and healthy controls [69]. The serum level of IL-31, but not those of IL-13 and IL-33, was found to be significantly elevated in hemodialysis patients compared with that in healthy controls. However, the serum level of IL-13, but not those of IL-31 and IL-33, was revealed to be significantly correlated with itch intensity [69]. Serum and cutaneous levels of IL-31 are also elevated in cutaneous T-cell lymphoma [19,70-73] and are described as being correlated with itch intensity in some reports $[19,73]$. In addition, the serum level of IL-31 is also increased in patients with intrahepatic cholestasis of pregnancy and hepatitis B virus-related liver cirrhosis, which are often associated with pruritus [74,75]. These studies stress the definite or potential role of IL-31 in pruritus induced by diverse skin disorders.

\section{Control of Pruritus by Targeting IL-31 Signaling}

The efficacy of anti-IL-31 treatment against pruritus was first proven in atopic dermatitis (Table 2).

Table 2. Biologics targeting IL-31.

\begin{tabular}{|c|c|c|}
\hline Antibody & Indication & Results \\
\hline $\begin{array}{l}\text { Nemolizumab } \\
\text { (anti-IL-31RA) } \\
\text { Single injection, [76] }\end{array}$ & $\begin{array}{l}\text { Moderate to severe } \\
\text { atopic dermatitis } \\
\text { (Phase } 1 / 1 b)\end{array}$ & $\begin{array}{l}\text { Safety profile is tolerable. } \\
\text { Significant reduction of pruritus (about }-50 \%) \text { than placebo } \\
(\text { about }-20 \% \text { ) at week } 4 \text {. }\end{array}$ \\
\hline $\begin{array}{l}\text { Nemolizumab } \\
\text { (anti-IL-31RA), [10] }\end{array}$ & $\begin{array}{l}\text { Moderate to severe } \\
\text { atopic dermatitis } \\
\text { (Phase } 2)\end{array}$ & $\begin{array}{l}\text { Significant reduction of pruritus }(-43.7 \% \text { in } 0.1 \mathrm{mg} / \mathrm{kg},-59.8 \% \\
\text { in } 0.5 \mathrm{mg} / \mathrm{kg} \text { and }-63.1 \% \text { in } 2 \mathrm{mg} / \mathrm{kg}) \text { than placebo }(-20.9 \%) \text { at } \\
\text { week } 12 .\end{array}$ \\
\hline $\begin{array}{l}\text { Nemolizumab } \\
\text { (anti-IL-31RA), [77] }\end{array}$ & $\begin{array}{l}\text { Moderate to severe } \\
\text { atopic dermatitis } \\
\text { (Phase 2) } \\
\text { (Long term study) }\end{array}$ & $\begin{array}{l}\text { Significant reduction of pruritus }(-73 \% \text { in } 0.1 \mathrm{mg} / \mathrm{kg},-89.6 \% \text { in } \\
0.5 \mathrm{mg} / \mathrm{kg} \text { and }-74.7 \% \text { in } 2 \mathrm{mg} / \mathrm{kg} \text { ) at week } 64 .\end{array}$ \\
\hline $\begin{array}{l}\text { Nemolizumab } \\
\text { (anti-IL-31RA), [78] }\end{array}$ & $\begin{array}{l}\text { Moderate to severe } \\
\text { atopic dermatitis } \\
\text { (Phase 2B) } \\
\text { (with topical steroids) }\end{array}$ & $\begin{array}{l}\text { Significant reduction of pruritus }(-42.8 \% \text { in } 60 \mathrm{mg} / \text { body) by } \\
\text { nemolizumab with topical steroid than placebo with topical } \\
\text { steroid }(-21.4 \%) \text { at week } 16 .\end{array}$ \\
\hline $\begin{array}{l}\text { Nemolizumab } \\
\text { (anti-IL-31RA), [79] }\end{array}$ & $\begin{array}{l}\text { Moderate to severe } \\
\text { atopic dermatitis } \\
\text { (Phase 2B) } \\
\text { (with topical steroids) }\end{array}$ & $\begin{array}{l}\text { Significant reduction of pruritus by nemolizumab with topical } \\
\text { steroid }(-67.3 \% \text { in } 30 \mathrm{mg} / \text { body) than placebo with topical steroid } \\
\qquad(-35.8 \%) \text { at week } 24 .\end{array}$ \\
\hline $\begin{array}{l}\text { Nemolizumab } \\
\text { (anti-IL-31RA), [80] }\end{array}$ & $\begin{array}{l}\text { Moderate to severe } \\
\text { atopic dermatitis } \\
\text { (Exploratory analysis) }\end{array}$ & $\begin{array}{l}\text { Significant improvement of work productivity and activity } \\
\text { impairment through week } 64 \text {. }\end{array}$ \\
\hline $\begin{array}{l}\text { Nemolizumab } \\
\text { (anti-IL-31RA), [11] }\end{array}$ & $\begin{array}{l}\text { Moderate to severe } \\
\text { prurigo nodularis } \\
\quad \text { (phase 2) }\end{array}$ & $\begin{array}{l}\text { Significant reduction of pruritus }(-53 \% \text { in } 0.5 \mathrm{mg} / \mathrm{kg}) \text { than } \\
\text { placebo }(-20.2 \%) \text { at week } 4 .\end{array}$ \\
\hline $\begin{array}{l}\text { Vixarelimab } \\
(\text { anti-OSMR } \beta),[81]\end{array}$ & $\begin{array}{l}\text { Moderate to severe } \\
\text { prurigo nodularis } \\
\text { (Phase } 2 a / 2 b)\end{array}$ & In clinical trial \\
\hline
\end{tabular}


Monotherapy with the anti-IL-31RA antibody nemolizumab was found to significantly attenuate the pruritus in atopic dermatitis compared with placebo control [10,76], for as long as 64 weeks [77]. Concomitant use of nemolizumab further enhanced the anti-pruritic effects of topical steroid $[78,79]$. Nemolizumab also improved dermatitis severity, sleep disturbance, quality of life and impairment of work productivity/activity [78-80]. In addition, the safety profile of nemolizumab is acceptable, without any notable severe adverse events [78,79]. Moreover, in canine atopic dermatitis, anti-canine IL-31 antibody (lokivetmab) significantly inhibited scratching in dogs with canine atopic dermatitis [82-85]. Proactive treatment with lokivetmab also reduced the flare of canine atopic dermatitis [85].

Recently, nemolizumab has also been reported to attenuate pruritus and skin inflammation associated with prurigo nodularis compared with placebo [11]. In addition, the anti-OSMR $\beta$ antibody vixarelimab (KPL-716) is now under a clinical trial for the treatment of prurigo nodularis (ClinicalTrials.gov Identifier: NCT03816891) [81].

\section{Conclusions}

Pruritus is a specific sensation associated with skin inflammation, such as atopic dermatitis and prurigo nodularis. Pruritus is also associated with systemic disorders such as kidney and liver diseases. Since chronic pruritus markedly deteriorates the quality of life of afflicted individuals, its therapeutic control is important. Recent studies have elucidated a close relationship of pruritus with IL-31, which is produced by Th2 cells, macrophages, dendritic cells and eosinophils. In accordance with this, intervention in the binding of IL-31 to its specific receptor IL-31RA/OSMR $\beta$ by specific antibodies has been proven to inhibit the pruritus in atopic dermatitis and prurigo nodularis. Targeting the IL-31 signal may thus be a promising strategy for improving the pruritus associated with diverse skin diseases.

Author Contributions: M.F. (Masutaka Furue) wrote the first draft of the manuscript. M.F. (Mihoko Furue) made Tables and Figures. Both authors revised the manuscript and approved its submission. All authors have read and agreed to the published version of the manuscript.

Funding: This research received no external funding.

Conflicts of Interest: The authors declare no conflict of interest.

\section{References}

1. Furue, M.; Kadono, T. New therapies for controlling atopic itch. J. Dermatol. 2015, 42, 847-850. [CrossRef] [PubMed]

2. Kido-Nakahara, M.; Furue, M.; Ulzii, D.; Nakahara, T. Itch in Atopic Dermatitis. Immunol. Allergy Clin. N. Am. 2017, 37, 113-122. [CrossRef] [PubMed]

3. Erickson, S.; Heul, A.V.; Kim, B.S. New and emerging treatments for inflammatory itch. Ann. Allergy Asthma Immunol. 2021, 126, 13-20. [CrossRef]

4. Newsom, M.; Bashyam, A.M.; Balogh, E.A.; Feldman, S.R.; Strowd, L.C. New and emerging systemic treatments for atopic dermatitis. Drugs 2020, 80, 1041-1052. [CrossRef]

5. Whang, K.A.; Khanna, R.; Williams, K.A.; Mahadevan, V.; Semenov, Y.; Kwatra, S.G. Health-related QOL and economic burden of chronic pruritus. J. Investig. Dermatol. 2020, 14. [CrossRef] [PubMed]

6. Takeuchi, S.; Yasukawa, F.; Furue, M.; Katz, S.I. Collared mice: A model to assess the effects of scratching. J. Dermatol. Sci. 2010, 57, 44-50. [CrossRef] [PubMed]

7. Akiyama, T.; Carstens, E. Neural processing of itch. Neuroscience 2013, 250, 697-714. [CrossRef] [PubMed]

8. Carstens, E.; Akiyama, T. Central mechanisms of itch. Curr. Probl. Dermatol. 2016, 50, 11-17.

9. Xing, Y.; Steele, H.R.; Hilley, H.B.; Zhu, Y.; Lawson, K.; Niehoff, T.; Han, L. Visualizing the itch-sensing skin arbors. J. Investig. Dermatol. 2020, 20. [CrossRef] [PubMed]

10. Ruzicka, T.; Hanifin, J.M.; Furue, M.; Pulka, G.; Mlynarczyk, I.; Wollenberg, A.; Galus, R.; Etoh, T.; Mihara, R.; Yoshida, H.; et al. Anti-interleukin-31 receptor A antibody for atopic dermatitis. N. Engl. J. Med. 2017, 376, 826-835. [CrossRef]

11. Ständer, S.; Yosipovitch, G.; Legat, F.J.; Lacour, J.P.; Paul, C.; Narbutt, J.; Bieber, T.; Misery, L.; Wollenberg, A.; Reich, A.; et al. Trial of nemolizumab in moderate-to-severe prurigo nodularis. N. Engl. J. Med. 2020, 382, 706-716. [CrossRef]

12. Furue, M.; Yamamura, K.; Kido-Nakahara, M.; Nakahara, T.; Fukui, Y. Emerging role of interleukin-31 and interleukin-31 receptor in pruritus in atopic dermatitis. Allergy 2018, 73, 29-36. [CrossRef] [PubMed]

13. Stott, B.; Lavender, P.; Lehmann, S.; Pennino, D.; Durham, S.; Schmidt-Weber, C.B. Human IL-31 is induced by IL-4 and promotes TH2-driven inflammation. J. Allergy Clin. Immunol. 2013, 132, 446-454. [CrossRef] 
14. Hashimoto, T.; Satoh, T.; Yokozeki, H. Pruritus in ordinary scabies: IL-31 from macrophages induced by overexpression of thymic stromal lymphopoietin and periostin. Allergy 2019, 74, 1727-1737. [CrossRef] [PubMed]

15. Hashimoto, T.; Kursewicz, C.D.; Fayne, R.A.; Nanda, S.; Shah, S.M.; Nattkemper, L.; Yokozeki, H.; Yosipovitch, G. Pathophysiologic mechanisms of itch in bullous pemphigoid. J. Am. Acad. Dermatol. 2020, 83, 53-62. [CrossRef] [PubMed]

16. Hashimoto, T.; Kursewicz, C.D.; Fayne, R.A.; Nanda, S.; Shah, S.M.; Nattkemper, L.; Yokozeki, H.; Yosipovitch, G. Mechanisms of itch in stasis dermatitis: Significant role of IL-31 from macrophages. J. Investig. Dermatol. 2020, 140, 850-859. [CrossRef]

17. Hashimoto, T.; Nattkemper, L.A.; Kim, H.S.; Kursewicz, C.D.; Fowler, E.; Shah, S.M.; Nanda, S.; Fayne, R.A.; Paolini, J.F.; Romanelli, P.; et al. Itch intensity in prurigo nodularis is closely related to dermal interleukin-31, oncostatin M, IL-31 receptor alpha and oncostatin M receptor beta. Exp. Dermatol. 2021, 11. [CrossRef]

18. Xu, J.; Zanvit, P.; Hu, L.; Tseng, P.Y.; Liu, N.; Wang, F.; Liu, O.; Zhang, D.; Jin, W.; Guo, N.; et al. The cytokine TGF- $\beta$ induces interleukin-31 expression from dermal dendritic cells to activate sensory neurons and stimulate wound itching. Immunity 2020, 53, 371-383. [CrossRef] [PubMed]

19. Nattkemper, L.A.; Martinez-Escala, M.E.; Gelman, A.B.; Singer, E.M.; Rook, A.H.; Guitart, J.; Yosipovitch, G. Cutaneous T-cell lymphoma and pruritus: The expression of IL-31 and its receptors in the skin. Acta Derm. Venereol. 2016, 96, 894-898. [CrossRef] [PubMed]

20. Dai, X.; Okazaki, H.; Hanakawa, Y.; Murakami, M.; Tohyama, M.; Shirakata, Y.; Sayama, K. Eccrine sweat contains IL-1 $\alpha$, IL-1 $\beta$ and IL-31 and activates epidermal keratinocytes as a danger signal. PLoS ONE 2013, 8, e67666. [CrossRef] [PubMed]

21. Cornelissen, C.; Brans, R.; Czaja, K.; Skazik, C.; Marquardt, Y.; Zwadlo-Klarwasser, G.; Kim, A.; Bickers, D.R.; Lüscher-Firzlaff, J.; Lüscher, B.; et al. Ultraviolet B radiation and reactive oxygen species modulate interleukin-31 expression in T lymphocytes, monocytes and dendritic cells. Br. J. Dermatol. 2011, 165, 966-975. [CrossRef]

22. Maier, E.; Werner, D.; Duschl, A.; Bohle, B.; Horejs-Hoeck, J. Human Th2 but not Th9 cells release IL-31 in a STAT6/NF-kBdependent way. J. Immunol. 2014, 193, 645-654. [CrossRef] [PubMed]

23. Maier, E.; Mittermeir, M.; Ess, S.; Neuper, T.; Schmiedlechner, A.; Duschl, A.; Horejs-Hoeck, J. Prerequisites for functional interleukin 31 signaling and its feedback regulation by suppressor of cytokine signaling 3 (SOCS3). J. Biol. Chem. 2015, 290, 24747-24759. [CrossRef] [PubMed]

24. Sonkoly, E.; Muller, A.; Lauerma, A.I.; Pivarcsi, A.; Soto, H.; Kemeny, L.; Alenius, H.; Dieu-Nosjean, M.C.; Meller, S.; Rieker, J.; et al. IL-31: A new link between T cells and pruritus in atopic skin inflammation. J. Allergy Clin. Immunol. 2006, 117, 411-417. [CrossRef]

25. Niebuhr, M.; Mamerow, D.; Heratizadeh, A.; Satzger, I.; Werfel, T. Staphylococcal $\alpha$-toxin induces a higher T cell proliferation and interleukin-31 in atopic dermatitis. Int. Arch. Allergy Immunol. 2011, 156, 412-415. [CrossRef]

26. Calkins, C.M.; Barsness, K.; Bensard, D.D.; Vasquez-Torres, A.; Raeburn, C.D.; Meng, X.; McIntyre, R.C., Jr. Toll-like receptor-4 signaling mediates pulmonary neutrophil sequestration in response to gram-positive bacterial enterotoxin. J. Surg. Res. 2002, 104, 124-130. [CrossRef]

27. O'Shea, J.J.; Lahesmaa, R.; Vahedi, G.; Laurence, A.; Kanno, Y. Genomic views of STAT function in CD4 ${ }^{+} \mathrm{T}$ helper cell differentiation. Nat. Rev. Immunol. 2011, 11, 239-250. [CrossRef]

28. Yamamura, K.; Uruno, T.; Shiraishi, A.; Tanaka, Y.; Ushijima, M.; Nakahara, T.; Watanabe, M.; Kido-Nakahara, M.; Tsuge, I.; Furue, M.; et al. The transcription factor EPAS1 links DOCK8 deficiency to atopic skin inflammation via IL-31 induction. Nat. Commun. 2017, 8, 13946. [CrossRef]

29. Koizume, S.; Ito, S.; Miyagi, E.; Hirahara, F.; Nakamura, Y.; Sakuma, Y.; Osaka, H.; Takano, Y.; Ruf, W.; Miyagi, Y. HIF2 $\alpha$-Sp1 interaction mediates a deacetylation-dependent FVII-gene activation under hypoxic conditions in ovarian cancer cells. Nucleic Acids Res. 2012, 40, 5389-5401. [CrossRef] [PubMed]

30. Xie, L.; Collins, J.F. Transcription factors Sp1 and Hif2 $\alpha$ mediate induction of the copper-transporting ATPase (Atp7a) gene in intestinal epithelial cells during hypoxia. J. Biol. Chem. 2013, 288, 23943-23952. [CrossRef] [PubMed]

31. Hanna, C.; Hubchak, S.C.; Liang, X.; Rozen-Zvi, B.; Schumacker, P.T.; Hayashida, T.; Schnaper, H.W. Hypoxia-inducible factor-2 $\alpha$ and TGF- $\beta$ signaling interact to promote normoxic glomerular fibrogenesis. Am. J. Physiol. Renal Physiol. 2013, 305, F1323-F1331. [CrossRef] [PubMed]

32. Lisk, C.; Kominsky, D.; Ehrentraut, S.; Bonaventura, J.; Nuss, R.; Hassell, K.; Nozik-Grayck, E.; Irwin, D.C. Hemoglobin-induced endothelial cell permeability is controlled, in part, via a myeloid differentiation primary response gene-88-dependent signaling mechanism. Am. J. Respir. Cell Mol. Biol. 2013, 49, 619-626. [CrossRef] [PubMed]

33. Bilsborough, J.; Leung, D.Y.; Maurer, M.; Howell, M.; Boguniewicz, M.; Yao, L.; Storey, H.; LeCiel, C.; Harder, B.; Gross, J.A. IL-31 is associated with cutaneous lymphocyte antigen-positive skin homing T cells in patients with atopic dermatitis. J. Allergy Clin. Immunol. 2006, 117, 418-425. [CrossRef] [PubMed]

34. Edukulla, R.; Singh, B.; Jegga, A.G.; Sontake, V.; Dillon, S.R.; Madala, S.K. Th2 Cytokines Augment IL-31/IL-31RA Interactions via STAT6-dependent IL-31RA Expression. J. Biol. Chem. 2015, 290, 13510-13520. [CrossRef]

35. Miake, S.; Tsuji, G.; Takemura, M.; Hashimoto-Hachiya, A.; Vu, Y.H.; Furue, M.; Nakahara, T. IL-4 augments IL-31/IL-31 receptor alpha interaction leading to enhanced $\mathrm{ccl} 17$ and $\mathrm{ccl} 22$ production in dendritic cells: Implications for atopic dermatitis. Int. J. Mol. Sci. 2019, 20, 4053. [CrossRef]

36. Kasraie, S.; Niebuhr, M.; Baumert, K.; Werfel, T. Functional effects of interleukin 31 in human primary keratinocytes. Allergy 2011, 66, 845-852. [CrossRef] 
37. Kasraie, S.; Niebuhr, M.; Werfel, T. Interleukin (IL)-31 activates signal transducer and activator of transcription (STAT)-1, STAT-5 and extracellular signal-regulated kinase $1 / 2$ and down-regulates IL-12p40 production in activated human macrophages. Allergy 2013, 68, 739-747. [CrossRef]

38. Cornelissen, C.; Marquardt, Y.; Czaja, K.; Wenzel, J.; Frank, J.; Lüscher-Firzlaff, J.; Lüscher, B.; Baron, J.M. IL-31 regulates differentiation and filaggrin expression in human organotypic skin models. J. Allergy Clin. Immunol. 2012, 129, $426-433$. [CrossRef] [PubMed]

39. Dillon, S.R.; Sprecher, C.; Hammond, A.; Bilsborough, J.; Rosenfeld-Franklin, M.; Presnell, S.R.; Haugen, H.S.; Maurer, M.; Harder, B.; Johnston, J.; et al. Interleukin 31, a cytokine produced by activated T cells, induces dermatitis in mice. Nat. Immunol. 2004, 5, 752-760. [CrossRef]

40. Cevikbas, F.; Wang, X.; Akiyama, T.; Kempkes, C.; Savinko, T.; Antal, A.; Kukova, G.; Buhl, T.; Ikoma, A.; Buddenkotte, J.; et al. A sensory neuron-expressed IL-31 receptor mediates T helper cell-dependent itch: Involvement of TRPV1 and TRPA1. J. Allergy Clin. Immunol. 2014, 133, 448-460. [CrossRef] [PubMed]

41. Kasutani, K.; Fujii, E.; Ohyama, S.; Adachi, H.; Hasegawa, M.; Kitamura, H.; Yamashita, N. Anti-IL-31 receptor antibody is shown to be a potential therapeutic option for treating itch and dermatitis in mice. Br. J. Pharmacol. 2014, 171, 5049-5058. [CrossRef] [PubMed]

42. Gonzales, A.J.; Humphrey, W.R.; Messamore, J.E.; Fleck, T.J.; Fici, G.J.; Shelly, J.A.; Teel, J.F.; Bammert, G.F.; Dunham, S.A.; Fuller, T.E.; et al. Interleukin-31: Its role in canine pruritus and naturally occurring canine atopic dermatitis. Vet. Dermatol. 2013, 24, 48-53. [CrossRef] [PubMed]

43. Gonzales, A.J.; Fleck, T.J.; Humphrey, W.R.; Galvan, B.A.; Aleo, M.M.; Mahabir, S.P.; Tena, J.K.; Greenwood, K.G.; McCall, R.B. IL-31-induced pruritus in dogs: A novel experimental model to evaluate anti-pruritic effects of canine therapeutics. Vet. Dermatol. 2016, 27, 34. [CrossRef] [PubMed]

44. Lewis, K.E.; Holdren, M.S.; Maurer, M.F.; Underwood, S.; Meengs, B.; Julien, S.H.; Byrnes-Blake, K.A.; Freeman, J.A.; Bukowski, T.R.; Wolf, A.C.; et al. Interleukin (IL) 31 induces in cynomolgus monkeys a rapid and intense itch response that can be inhibited by an IL-31 neutralizing antibody. J. Eur. Acad. Dermatol. Venereol. 2017, 31, 142-150. [CrossRef] [PubMed]

45. Oyama, S.; Kitamura, H.; Kuramochi, T.; Higuchi, Y.; Matsushita, H.; Suzuki, T.; Goto, M.; Adachi, H.; Kasutani, K.; Sakamoto, A.; et al. Cynomolgus monkey model of interleukin-31-induced scratching depicts blockade of human interleukin-31 receptor A by a humanized monoclonal antibody. Exp. Dermatol. 2018, 27, 14-21. [CrossRef]

46. Hawro, T.; Saluja, R.; Weller, K.; Altrichter, S.; Metz, M.; Maurer, M. Interleukin-31 does not induce immediate itch in atopic dermatitis patients and healthy controls after skin challenge. Allergy 2014, 69, 113-117. [CrossRef]

47. Singh, B.; Jegga, A.G.; Shanmukhappa, K.S.; Edukulla, R.; Khurana Hershey, G.H.; Medvedovic, M.; Dillon, S.R.; Madala, S.K. IL-31-driven skin remodeling involves epidermal cell proliferation and thickening that lead to impaired skin-barrier function. PLoS ONE 2016, 11, e0161877. [CrossRef] [PubMed]

48. Feld, M.; Garcia, R.; Buddenkotte, J.; Katayama, S.; Lewis, K.; Muirhead, G.; Hevezi, P.; Plesser, K.; Schrumpf, H.; Krjutskov, K.; et al. The pruritus- and TH2-associated cytokine IL-31 promotes growth of sensory nerves. J. Allergy Clin. Immunol. 2016, 138, 500-508. [CrossRef] [PubMed]

49. Grimstad, O.; Sawanobori, Y.; Vestergaard, C.; Bilsborough, J.; Olsen, U.B.; Grønhøj-Larsen, C.; Matsushima, K. Anti-interleukin31-antibodies ameliorate scratching behaviour in NC/Nga mice: A model of atopic dermatitis. Exp. Dermatol. 2009, 18, 35-43. [CrossRef]

50. Mochizuki, H.; Kakigi, R. Itch and brain. J. Dermatol. 2015, 42, 761-767. [CrossRef] [PubMed]

51. Sakai, K.; Akiyama, T. New insights into the mechanisms behind mechanical itch. Exp. Dermatol. 2020, 29, 680-686. [CrossRef]

52. Kato, A.; Fujii, E.; Watanabe, T.; Takashima, Y.; Matsushita, H.; Furuhashi, T.; Morita, A. Distribution of IL-31 and its receptor expressing cells in skin of atopic dermatitis. J. Dermatol. Sci. 2014, 74, 229-235. [CrossRef] [PubMed]

53. Oetjen, L.K.; Mack, M.R.; Feng, J.; Whelan, T.M.; Niu, H.; Guo, C.J.; Chen, S.; Trier, A.M.; Xu, A.Z.; Tripathi, S.V.; et al. Sensory neurons co-opt classical immune signaling pathways to mediate chronic itch. Cell 2017, 171, 217-228. [CrossRef]

54. Campion, M.; Smith, L.; Gatault, S.; Métais, C.; Buddenkotte, J.; Steinhoff, M. Interleukin-4 and interleukin-13 evoke scratching behaviour in mice. Exp. Dermatol. 2019, 28, 1501-1504. [CrossRef] [PubMed]

55. Bautista, D.M.; Wilson, S.R.; Hoon, M.A. Why we scratch an itch: The molecules, cells and circuits of itch. Nat. Neurosci. 2014, 17, 175-182. [CrossRef] [PubMed]

56. Sakata, D.; Uruno, T.; Matsubara, K.; Andoh, T.; Yamamura, K.; Magoshi, Y.; Kunimura, K.; Kamikaseda, Y.; Furue, M.; Fukui, Y. Selective role of neurokinin B in IL-31-induced itch response in mice. J. Allergy Clin. Immunol. 2019, 144, 1130-1133. [CrossRef]

57. Kido-Nakahara, M.; Wang, B.; Ohno, F.; Tsuji, G.; Ulzii, D.; Takemura, M.; Furue, M.; Nakahara, T. Inhibition of mite-induced dermatitis, pruritus, and nerve sprouting in mice by the endothelin receptor antagonist bosentan. Allergy 2021, 76, $291-301$. [CrossRef] [PubMed]

58. Shiratori-Hayashi, M.; Koga, K.; Tozaki-Saitoh, H.; Kohro, Y.; Toyonaga, H.; Yamaguchi, C.; Hasegawa, A.; Nakahara, T.; Hachisuka, J.; Akira, S.; et al. STAT3-dependent reactive astrogliosis in the spinal dorsal horn underlies chronic itch. Nat. Med. 2015, 21, 927-931. [CrossRef]

59. van Drongelen, V.; Haisma, E.M.; Out-Luiting, J.J.; Nibbering, P.H.; El Ghalbzouri, A. Reduced filaggrin expression is accompanied by increased Staphylococcus aureus colonization of epidermal skin models. Clin. Exp. Allergy 2014, 44, 1515-1524. [CrossRef] 
60. Hänel, K.H.; Pfaff, C.M.; Cornelissen, C.; Amann, P.M.; Marquardt, Y.; Czaja, K.; Kim, A.; Lüscher, B.; Baron, J.M. Control of the physical and antimicrobial skin barrier by an IL-31-IL-1 signaling network. J. Immunol. 2016, 196, 3233-3244. [CrossRef]

61. Nobbe, S.; Dziunycz, P.; Mühleisen, B.; Bilsborough, J.; Dillon, S.R.; French, L.E.; Hofbauer, G.F. IL-31 expression by inflammatory cells is preferentially elevated in atopic dermatitis. Acta Derm. Venereol. 2012, 92, 24-28.

62. Szegedi, K.; Kremer, A.E.; Kezic, S.; Teunissen, M.B.; Bos, J.D.; Luiten, R.M.; Res, P.C.; Middelkamp-Hup, M.A. Increased frequencies of IL-31-producing T cells are found in chronic atopic dermatitis skin. Exp. Dermatol. 2012, 21, 431-436. [CrossRef]

63. Ezzat, M.H.; Hasan, Z.E.; Shaheen, K.Y. Serum measurement of interleukin-31 (IL-31) in paediatric atopic dermatitis: Elevated levels correlate with severity scoring. J. Eur. Acad. Dermatol. Venereol. 2011, 25, 334-339. [CrossRef] [PubMed]

64. Raap, U.; Weißmantel, S.; Gehring, M.; Eisenberg, A.M.; Kapp, A.; Fölster-Holst, R. IL-31 significantly correlates with disease activity and Th2 cytokine levels in children with atopic dermatitis. Pediatric Allergy Immunol. 2012, 23, 285-288. [CrossRef] [PubMed]

65. Chaudhary, S.K.; Singh, S.K.; Kumari, P.; Kanwal, S.; Soman, S.P.; Choudhury, S.; Garg, S.K. Alterations in circulating concentrations of IL-17, IL-31 and total IgE in dogs with atopic dermatitis. Vet. Dermatol. 2019, 30, 383. [CrossRef] [PubMed]

66. Salao, K.; Sawanyawisuth, K.; Winaikosol, K.; Choonhakarn, C.; Chaowattanapanit, S. Interleukin-31 and chronic pruritus of unknown origin. Biomark. Insights 2020, 15. [CrossRef] [PubMed]

67. Chaowattanapanit, S.; Choonhakarn, C.; Salao, K.; Winaikosol, K.; Julanon, N.; Wongjirattikarn, R.; Foocharoen, C.; Sompornrattanaphan, M. Increased serum IL-31 levels in chronic spontaneous urticaria and psoriasis with pruritic symptoms. Heliyon 2020, 6, e05621. [CrossRef] [PubMed]

68. Ko, M.J.; Peng, Y.S.; Chen, H.Y.; Hsu, S.P.; Pai, M.F.; Yang, J.Y.; Wen, S.Y.; Jee, S.H.; Wu, H.Y.; Chiu, H.C. Interleukin-31 is associated with uremic pruritus in patients receiving hemodialysis. J. Am. Acad. Dermatol. 2014, 71, 1151-1159. [CrossRef]

69. Oweis, A.O.; Al-Qarqaz, F.; Bodoor, K.; Heis, L.; Alfaqih, M.A.; Almomani, R.; Obeidat, M.A.; Alshelleh, S.A. Elevated interleukin 31 serum levels in hemodialysis patients are associated with uremic pruritus. Cytokine 2021, 138, 155369. [CrossRef]

70. Ohmatsu, H.; Sugaya, M.; Suga, H.; Morimura, S.; Miyagaki, T.; Kai, H.; Kagami, S.; Fujita, H.; Asano, Y.; Tada, Y.; et al. Serum IL-31 levels are increased in patients with cutaneous T-cell lymphoma. Acta Derm. Venereol. 2012, 92, 282-283. [CrossRef]

71. Malek, M.; Gleń, J.; Rębała, K.; Kowalczyk, A.; Sobjanek, M.; Nowicki, R.; Ruckemann-Dziurdzińska, K.; Sokołowska-Wojdyło, M. Il-31 does not correlate to pruritus related to early stage cutaneous T-cell lymphomas but is involved in pathogenesis of the disease. Acta Derm. Venereol. 2015, 95, 283-288. [CrossRef] [PubMed]

72. Ferretti, E.; Tripodo, C.; Pagnan, G.; Guarnotta, C.; Marimpietri, D.; Corrias, M.V.; Ribatti, D.; Zupo, S.; Fraternali-Orcioni, G.; Ravetti, J.L.; et al. The interleukin (IL)-31/IL-31R axis contributes to tumor growth in human follicular lymphoma. Leukemia 2015, 29, 958-967. [CrossRef] [PubMed]

73. Cedeno-Laurent, F.; Singer, E.M.; Wysocka, M.; Benoit, B.M.; Vittorio, C.C.; Kim, E.J.; Yosipovitch, G.; Rook, A.H. Improved pruritus correlates with lower levels of IL-31 in CTCL patients under different therapeutic modalities. Clin. Immunol. 2015, 158, 1-7. [CrossRef] [PubMed]

74. Basile, F.; Santamaria, A.; Mannucci, C.; Rizzo, L.; Gangemi, S.; D’anna, R.; Arcoraci, V. Interleukin 31 is involved in intrahepatic cholestasis of pregnancy. J. Matern. Fetal Neonatal Med. 2017, 30, 1124-1127. [CrossRef] [PubMed]

75. Ming, D.; Yu, X.; Guo, R.; Deng, Y.; Li, J.; Lin, C.; Su, M.; Lin, Z.; Su, Z. Elevated TGF- $\beta 1 /$ IL-31 Pathway Is Associated with the Disease Severity of Hepatitis B Virus-Related Liver Cirrhosis. Viral Immunol. 2015, 28, 209-216. [CrossRef] [PubMed]

76. Nemoto, O.; Furue, M.; Nakagawa, H.; Shiramoto, M.; Hanada, R.; Matsuki, S.; Imayama, S.; Kato, M.; Hasebe, I.; Taira, K.; et al. The first trial of CIM331, a humanized antihuman interleukin-31 receptor A antibody, in healthy volunteers and patients with atopic dermatitis to evaluate safety, tolerability and pharmacokinetics of a single dose in a randomized, double-blind, placebo-controlled study. Br. J. Dermatol. 2016, 174, 296-304.

77. Kabashima, K.; Furue, M.; Hanifin, J.M.; Pulka, G.; Wollenberg, A.; Galus, R.; Etoh, T.; Mihara, R.; Nakano, M.; Ruzicka, T. Nemolizumab in patients with moderate-to-severe atopic dermatitis: Randomized, phase II, long-term extension study. J. Allergy Clin. Immunol. 2018, 142, 1121-1130. [CrossRef]

78. Kabashima, K.; Matsumura, T.; Komazaki, H.; Kawashima, M. Trial of nemolizumab and topical agents for atopic dermatitis with pruritus. N. Engl. J. Med. 2020, 383, 141-150. [CrossRef]

79. Silverberg, J.I.; Pinter, A.; Pulka, G.; Poulin, Y.; Bouaziz, J.D.; Wollenberg, A.; Murrell, D.F.; Alexis, A.; Lindsey, L.; Ahmad, F.; et al. Phase 2B randomized study of nemolizumab in adults with moderate-to-severe atopic dermatitis and severe pruritus. J. Allergy Clin. Immunol. 2020, 145, 173-182. [CrossRef]

80. Mihara, R.; Kabashima, K.; Furue, M.; Nakano, M.; Ruzicka, T. Nemolizumab in moderate to severe atopic dermatitis: An exploratory analysis of work productivity and activity impairment in a randomized phase II study. J. Dermatol. 2019, 46, 662-671. [CrossRef]

81. Study to assess the efficacy, safety, and tolerability of vixarelimab in reducing pruritus in prurigo nodularis. Available online: https: / / clinicaltrials.gov/ct2/ show / NCT03816891?term=KPL-716\&cond=prurigo+nodularis\&draw=2\&rank=1 (accessed on 4 March 2021).

82. Michels, G.M.; Ramsey, D.S.; Walsh, K.F.; Martinon, O.M.; Mahabir, S.P.; Hoevers, J.D.; Walters, R.R.; Dunham, S.A. A blinded, randomized, placebo-controlled, dose determination trial of lokivetmab (ZTS-00103289), a caninized, anti-canine IL-31 monoclonal antibody in client owned dogs with atopic dermatitis. Vet. Dermatol. 2016, 27, 478. [CrossRef] [PubMed] 
83. Moyaert, H.; Van Brussel, L.; Borowski, S.; Escalada, M.; Mahabir, S.P.; Walters, R.R.; Stegemann, M.R. A blinded, randomized clinical trial evaluating the efficacy and safety of lokivetmab compared to ciclosporin in client-owned dogs with atopic dermatitis. Vet. Dermatol. 2017, 28, 593. [CrossRef] [PubMed]

84. Szczepanik, M.; Wilkołek, P.; Gołyński, M.; Sitkowski, W.; Taszkun, I.; Toczek, W. The influence of treatment with lokivetmab on transepidermal water loss (TEWL) in dogs with spontaneously occurring atopic dermatitis. Vet. Dermatol. 2019, $30,330$. [CrossRef] [PubMed]

85. Tamamoto-Mochizuki, C.; Paps, J.S.; Olivry, T. Proactive maintenance therapy of canine atopic dermatitis with the anti-IL-31 lokivetmab. Can a monoclonal antibody blocking a single cytokine prevent allergy flares? Vet. Dermatol. 2019, 23. [CrossRef] 